\title{
Olive Drab in Black and White: The Brazilian Expeditionary Force, the US Army and Racial National Identity*
}

\section{Verde-oliva em preto e branco: a força expedicionária brasileira, o exército dos EUA, e identidade nacional racial}

Uri Rosenheck**

\begin{abstract}
When the Brazilian Expeditionary Force arrived in Italy to fight alongside the Allies in WWII, its members were introduced to the racially segregated US Army. Based on memoirs, published oral testimonies, newspapers, and comics, this paper explores the ways in which Brazilians of all walks of life - rather than ideology-producing elites - projected their own perceptions on race relations and what it meant racially to be a Brazilian. Their representations, however, were not uniform. Rather, they offered an array of alternative racial national identities varying from whole-white troops to zealous support of their "Racial Democracy." Civil rights activists in the United States used these images to condemn their domestic racial segregation while some Brazilians criticized the Brazilian army's hypocrisy and racism.
\end{abstract}

Key-words: World War II; Brazilian Expeditionary Force; National Identity; Race Relations; Racial Democracy; Comics

\footnotetext{
*An earlier version of this article was presented at the XXIX International Congress of the Latin American Studies Association, October 6-9, 2010, Toronto, Canada. I would like to thank Aneilya Burns, Christopher Gunn, and Fabricio Prado for their useful comments.

** Professora do Departamento de História, Coastal Carolina University, Estados Unidos da América. Doutor em História pela Emory University. E-mail: urirosenheck@gmail.com
} 
Resumo: Quando a Força Expedicionária Brasileira chegou à Italia para lutar com os aliados na Segunda Guerra Mundial, seus integrantes foram introduzidos à segregação racial presente no exército dos EUA. Com base em memórias e histórias orais já publicadas, jornais e historias em quadrinhos, este artigo explora as maneiras pelas quais os brasileiros de diferentes grupos sociais, e não apenas as elites, projetavam suas próprias percepções sobre relações raciais e o significado de "ser brasileiro". Essas representações, entretanto, não eram uniformes. Em vez disso, eles ofereceriam uma variedade de identidades nacionais raciais alternativas que variam da noção de tropas completamente brancas a um apoio zeloso de sua "democracia racial". Ativistas de direitos civis nos Estados Unidos usaram essas representações para condenar a segregação racial doméstica, enquanto alguns brasileiros criticaram a hipocrisia e o racismo do exército brasileiro.

Palavras-chave: Segunda Guerra Mundial; Força expedicionária brasileira; Identidade nacional; Relações raciais; Democracia racial; Historias em quadrinhos.

After their return from Europe, veterans of the Brazilian Expeditionary Force (Força expedicionária brasileira, hence forth: FEB) who fought in WWII alongside the Allies in Italy were met with mixed reactions. While the majority of their compatriots celebrated their return and glorified their role in the victorious campaign, some contemporary critics doubted their military performance and referred to the returning soldiers - now stronger, better built, better fed, and tanned - as tourists. ${ }^{1}$ The pejorative image lingered in some circles, and as late as 2005 Joel Silveira, a prominent journalist who served as a war correspondent with the FEB and a prolific writer on the war, chose the title "It Wasn't a Tour" (Não foi um passeio) for his introduction to a collection of some of his war-time old columns to disprove the aged perception of the FEB. ${ }^{2}$

There was, however, a grain of unintentional truth in the description of the soldiers as travelers to distant lands. For most of the 25,000 pracinhas, as the soldiers were fondly known, the war was an experience of a lifetime. It was their first trip outside their slumberous towns, not to mention abroad. It was their first crossing of the Atlantic, and their first visit to Classic Europe. ${ }^{3}$ While on duty and during vacations, Brazilian soldiers met civilians and soldiers of different nationalities and visited Italy's landmarks. In fact, in their memoirs some veterans also refer to some aspects of their experiences in the FEB as tourism. ${ }^{4}$

The conceptualization of soldiers' experiences in war as a form of tourism is not unique to Brazilians. ${ }^{5}$ While studying tourism in post-WWII Germany and the construction of national identity, Alon Confino observes that tourism is a practice of encounter with the different. In this process, 
he continues, the tourist inevitably compares the two cultures and evaluates them one against the other. ${ }^{6}$ In her study of travel narratives, Mary Louis Pratt describes such encounters - although in a colonial context — as "contact zones," which she defines as "social spaces where disparate cultures meet, clash, and grapple with each other, often in highly asymmetrical relations of domination and subordination." 7 While in Italy, the Brazilian soldiers came across more than one dissimilar culture.

Years and decades later, veterans described such encounters in their testimonies, memoirs, and other representations of their wartime experiences. They often narrate their meetings with "others" in the Italian contact zones in anecdotes. Stephen Greenblatt argues that anecdotes made by travelers are representative anecdotes and are "among the principle products of a culture's representational technology." 8 Thus, Greenblatt asserts that these anecdotes are literary units that are more than a particular story of a personal experience, but are also highly telling as an emblematic event, representative of a wider, cultural experience.

Accordingly, the Brazilian soldiers' reflections — even when anecdotalon their past encounters with dissimilar cultures in the Italian contact zones should be understood as made by representative cultural agents carrying a cultural baggage and reflecting upon it, rather than merely projecting their subjective personal experiences.

Upon arriving in Italy, Brazilian soldiers had opportunities to engage with North American soldiers. ${ }^{9}$ Many Brazilians were very impressed by many aspects of the US troops, especially their commanders' respect for their soldiers, the spirit of the soldier-citizen, and their focus on combat performance and practicality rather than formal discipline and military hierarchy. While these impressions generated harsh self-criticism among the soldiers-especially among the reserves low-ranking officers - there was one aspect of the U.S. Army that shocked the Brazilians - racial segregation. This article focuses on the Brazilians' encounter with a different model of racial relations and their reflections on Brazil's own racial relations that the encounter provoked and revealed.

\section{Witnessing Jim Crow}

During the Second World War, the US segregated army reflected the racial values of the American society. Black and white American soldiers served in separate unites, and lived their military lives in the front and rear divorced from one another. The military assigned most Afro-Americans to serve in auxiliary unites, and only a few to combat units, such as the famous Taskegee aviation squadron, the Ninety-Third infantry division that fought in the Pacific theatre, and the Ninety-Second "Buffalo" infantry division that 
fought in Italy alongside the Brazilians. Those infantry divisions were manned by Afro-American troops, NCO's, and low-ranking officers up to the rank of captain. Other officers and the unit's upper command were all white, many of which, by design, from the southern states of the United States.

When the Brazilians initially encountered the segregated US army, they reacted with curiosity, amazement, and shock to the mere idea that such a practice existed. For example, when recalling his discovery that the Americans have segregated units, Benno Armindo Schirmer's used the term "a curios thing" (coisa curiosa) to describe the system. ${ }^{10}$ For some, the concept of institutional discrimination was completely alien. Thus, decades after the campaign Miguel Ferreira de Lima explained the segregation he witnessed in the following manner: "[ $\mathrm{t}]$ here was a very deep separation, actual racism, because the Americans had no law about it, [they] differentiated between people." ${ }^{\prime 1}$ According to this comment, Ferreira de Lima did not grasp the fact that American racism was enforced by the law rather than existed despite of it. While Schirmer and Ferreira de Lima found segregation curious and alien, Jarbas Albricker well comprehended the segregation he witnessed while he was in the United States for training before the campaign. In his memoir he narrates his reaction to the segregated buses in Miami and how he became "Amazed by the problem of the black men," and commenting: "[w] hat subhumanity!"12 Other veterans described segregation in similar terms such as "apartheid" and "monstrosity." 13

As time went by, the Brazilians had more opportunities to observe how white Americans treated their fellow Afro-American soldiers. Gradually they grasped the subtleties of their northern neighbors' racial relations and discriminatory attitudes, as well as the consequences of this treatment. After about two weeks of working in the Evacuation Hospital 38, surgeon Alípio Corrêa Netto observed that the North Americans systematically assigned the wounded black soldiers to the Brazilians. For him this was no coincidence, and, in his own words, the North Americans "they sought to test us by offering us, as if it was an experiment [to our technical ability], their colored compatriots." ${ }^{14}$ It is important to note that not all Brazilians shared Corrêa Netto's interpretation. Diaz Sebastião Cammarosano, who served as a nurse and observed American medical personnel at work as well, had an opposite impression:

In relation to the wounded, the Americans seemed to forget the problems of racism, although we knew that their prejudice against the black color remained latent. Often in our relationship, when we maintained contact with the Americans, they were always puzzled by the comradeship between white and black Brazilians ... But in relation to those wounded at war, the American physicians, understandably, kept the humanitarian spirit, overcoming 
color problems. ${ }^{15}$

In the Brazilians' eyes, not only North American segregation was a faulty practice, but it also impacted Afro-American units' performances. During the first and last months of the campaign, the Ninety-Second "Buffalo" black division operated alongside, in cooperation, and in the footsteps of the Brazilian Expeditionary Force. Some Brazilians noticed the white Americans' lack of confidence in their black troops. ${ }^{16}$ Soon, however, the Brazilians witnessed the Afro-Americans' performances and evaluated it themselves. The black troops did not impress the Brazilians, who repeatedly mention that the Americans were good soldiers, with the exception of the Afro-American units. ${ }^{17}$ Again and again veterans recalled unacceptable behaviors of the soldiers of the NinetySecond - particularly showing cowardice in front of the enemy, deserting the battlefield, and abandoning their firearms.

Almost unanimously, the Brazilians explain the African Americans' conduct as driven by their low morale, which in turn was the direct result of the tense race relations in the segregated US army and the discrimination they suffered. ${ }^{18}$ A representative evaluation can be found in Rubens Resstel's following description

The all-black American Division was already unmotivated, and every time this Division was covering our flank, we felt anxious, because with any manifestation of the Germans, they all ran away, because they did not want to sacrifice themselves for a nation and a people that disdained them. ${ }^{19}$

Octavio Perreira da Costa shares Resstel's assessment:

It was already a form of discrimination to form a regiment of blacks only. It was not a good Regiment, it left much to be desired in terms of motivation and, in consequence, combat efforts, and zeal for its equipment, which many of its members abandoned in their positions when they were substituted. They could not have motivation in a full racial segregation regime that existed then in the United States. This Regiment really demonstrated a disastrous performance. ${ }^{20}$

A few veterans even claimed that the Afro-American troops shared the same view and openly expressed their lack of motivation. Ernani Ferreira Lopes, for example, recalled an episode when Afro-American soldiers did not resist a German attack, and retreated to a location where they stayed unorganized and off-guard playing cards. After Lopes scolded their lieutenant and asked him what they were doing there, he cited the black lieutenant's response: "What am 
I doing here? What does a black man do here, if he does not have any rights in the United States and cannot even rise to a Battalion Commander? Defending what Democracy?"21

Several American historians of the Ninety-Second Division agree race has played a role in the black division's mediocre performance, although their reasoning slightly defers from the Brazilians' understanding of the mechanisms of racism. Mary Penick Motley, who compiled interviews and letters of black soldiers, chose to conclude her volume with a somewhat apologetic quotation of the Ninety-second's artillery battalion commander. Lieutenant Colonel Marcus Ray does blame racially-motivated personnel choices regarding junior officers - promoting inadequate white officers "who fit the Southern pattern" and humiliating blacks "who exhibit maligns and self-reliance and self-respect"- but assigned most responsibility to non-satisfactory leadership and professionalism of the division's high command. ${ }^{22}$ Daniel Gibran, too, concludes that race effected the black soldiers' motivation and performance. According to him, racial prejudice against the Afro-Americans by their own white commanders established lower expectations to their performance, and, thus, set them up for failure as a unit. ${ }^{23}$

Historians Dennison de Oliveira and Cesar Campiani Maximiano observed that while the Brazilians tended to blame the Ninety-Second Division's poor performance on American racism, they did not assign racial tension any importance when discussing Brazilian failures. ${ }^{24}$ It is this comment exactly-in addition to the American historians' alternative explanations - that emphasizes the fact that it was the Brazilians' choice to portray racial discrimination as the chief explanation for the black soldiers' performance. Their election to do so constitutes the first step in constructing a narrative about race relations in Brazil and in the United States. The darker the image of American racism is, the brighter the Brazilian mirror-image shines.

\section{Conquering the Moral High Ground}

Like other travelers in contact zones, the Brazilians who encountered an alien North American system of race relations turned their gaze to their own army and society. The Brazilians' amazement and shock are possible only because the reality they witnessed in Italy collided with their earlier knowledge of how such relations should look. In other words, the rejection of the North American model becomes possible - and is dependent upon - the existence of a different Brazilian model. Accordingly, veterans recalling their racial experiences repeatedly complement their narrative by contrasting American discrimination and segregated units with the integrated Brazilian Army and claims about the multi-racial nature of Brazilian society and its lack of racism. A 
representative example can be found in Elza Cansanção Medeiros's last section of the narrative on her experiences as a military nurse witnessing segregation in the US army:

\begin{abstract}
But, here in Brazil, there has never been this type of situation. Although [some] want to invent this story of apartheid...Well there is no point in sticking with this story, because there had been no prejudice in Brazil. There is an integration of the three races, thank God. The pure Brazilian race is a miscegenation. We are a little of each of them. It does not matter for us if people are black, yellow, red or white, what matters is the human being as a person, his moral integrity, his social behavior and not skin color. Skin color does not matter. And that is what is most beautiful. ${ }^{25}$
\end{abstract}

The condemnation of the North Americans is thus inseparable from the self-congratulating celebration of the soldiers' understanding of the Brazilian model of race relations.

The amazement of the encounter with a different system of race relations was mutual. Americans, according to the Brazilians, were also amazed of the lack of racism among the Brazilians. ${ }^{26}$ Even Afro-Americans were surprised to encounter the integrated Brazilian troops and were especially interested in the lack of racial military hierarchy in the form of Afro-Brazilians who held commanding positions over white Brazilians. A typical story can be found in João Ferreira Albuquerque's episode:

When we got to Lizano and Belvedere, a Division of black Americans replaced us. I was talking to a captain of theirs who found it strange [to see] a Brazilian black sergeant giving orders to a white soldier. I said that there was no problem because there was no prejudice in the Brazilian Army. If there was a black corporal, [he] could command a white soldier; I added that in a transmissions course I took there was a colored officer, a captain, who taught a class without any problem. He said he was amazed, because in his Division, from Major and up it could only be white people. They were admired to see us playing, between us this was nothing extraordinary. ${ }^{27}$

Admiration took over the surprise, and Brazilians often reported that the Afro-American troops liked them, and their wounded preferred to stay with the Brazilian medical staff. ${ }^{28}$

Back in the United States the participation of the racially-integrated Brazilian troops drew the attention of the Afro-American press. The Baltimore- 
based Afro-American published a photo of black and white Brazilian soldiers marching in Rio before embarking on the ship that would carry them to Italy and the title cried: "Black and White Fight Together for Brazil, why Not for U.S.A.?"29 On the same day, the New York Amsterdam News published the same photo and gave it an equally provocative title: "Brazil Shows How Democracy should Work." ${ }^{30}$ The image was very peculiar and unusual from the North American point of view, as is illustrated in another article that appeared in the New York Amsterdam News two weeks later. The article condemned the United States for not having racially-integrated units, and contrasted their absence with a British volunteer multi-racial Caribbean Regiment and the Brazilian troops. It also referred to the same image and described its effect the following:

The striking picture of the Brazilian soldiers marching, fully equipped, for action. The black faces were just as prominent as the faces of white Brazilians, and there seemed to be no friction regarding the particular ape or monkey from which each color or race came. ${ }^{31}$

On the same day, July 1, 1944, The New York-based People's Voice asked in its opinion column "Question of the Week" should President Roosevelt be blamed "for jimcro in the Armed Forces?" The opposing view mentioned the Brazilians as an example for the viability of racial equality among soldiers. ${ }^{32}$

In early August, The Pittsburgh Courier's war correspondent covered the Brazilians' arrival to Naples and how their presence in the streets "startled the ogling Neapolitans with the unprecedented spectacle of white, black and red troops obviously unconscious of any racial differences and enjoying the delights of the beautiful city." ${ }^{33}$ The Baltimore Afro-American's correspondent also reported "I learned also that there is no color question in Brazil or in its Army. The men I talked with either didn't understand why or know that we had separate forces." 34

The black press celebrated the "integrated" Brazilian troops - a term that suggested there were separate groups that were actively brought togetherbut also noticed that this was exceptional, a startling spectacle for African Americans and Italians alike. They used the FEB as a better alternative to their reality and as a benchmark for their "Double V Campaign" to use the war as leverage to promote their community's civil rights back home.

In Italy, not only Brazilians witnessed North American racial discrimination, but they also suffered from racial prejudice from friends and foes alike. These attitudes also provided the Brazilians with opportunities to demonstrate the superiority of their ideology of racial democracy over others' racist stereotypes. German propaganda warned the Italian civilian population of the "black" Brazilian troops and of the Afro-Brazilians who "eat children." The Brazilians, however, occasionally had some fun with the frightened 
Italian population and sent Afro-Brazilian soldiers to inquire where all the children were. Eventually, however, they won the civilians' affection with their generosity and kindness, and with the help of distributed candies. ${ }^{35}$

Beyond interviews and memoirs, war comics too commemorated Brazilian veterans and their stories. During the 1960s and 1970s, more than a hundred original war stories saw light in Brazil in the form of short comics in several comic journals. In these illustrated narratives Brazilian artists expressed and shaped their national identity in relation to the FEB. In some of these graphic stories comics authors put racially pejorative statements in the mouths of German protagonists and made them show their vanity based on their perceived racial superiority over the "inferior Brazilian black race." For example, in "Highway 64" one German expresses his astonishment at the Brazilians' accomplishments by saying: "Damned! How could an inferior race, how could blacks resist the snow? Demons!!!!"36 Additionally, in the story "Alberta" a German lieutenant mocks an Italian girl for her hopes that the Brazilians will free her by saying that the Brazilians are "savage blacks, inferior race. ${ }^{\prime 37}$ The stories enfold, then, to a Brazilian victory that disproves the Germans' claims for superiority and reinforce the Brazilians superior racial model.

Occasionally, Brazilians also sensed racial prejudice against them from their allies. Geraldo Carlos Leopoldo de Farias Portocarrero, for example, claimed that despite the usual politeness, the North Americans felt superior to the Brazilians, whom they perceived as "Latinos" or "non-whites." 38 Such claims provided the background to the most powerful and explicit comic story that eulogized the superiority of the Brazilian model of race relations. In the story "Weekend at the Front," two Brazilian soldiers are driving to Naples to socialize with Italian women. While on their way, the white soldier tells the black one that "The European is like the American: [for them] black is only good to go to war or to prison." His surprised comrade answers "But we don't have this in Brazil "Yeah!" the white soldier corrects his naïve comrade: Do you think everyone is like us?" 39

Therefore, as Maximiano and Oliveira argue, the ongoing encounter with the segregated US army reinforced the Brazilians' belief that in Brazil there was no racism..$^{40}$ It also allowed the Brazilians to claim the moral high ground and to eulogize the ideology of Racial Democracy. In their textual and visual narratives the veterans and the artists who told their stories created an ideal image of the Brazilian society. This post-racial utopia could hide, but not eliminate completely, the gap between their strong belief in the absence of racism, and the claims that it still existed in the Brazilian society.

\section{Looking at the Mirror}

While the Brazilians' claims of lack of racism are loud and clear, few- 
but vocal — voices told of cases of prejudice against blacks within the Brazilian army and condemned them. They question the ideal image the majority of the veterans portray, claim that racist episodes did happen in the FEB, and put a disturbing mirror in front of their compatriots.

José Dequech argues that the enlistment criteria for the FEB excluded Afro-Brazilians ${ }^{41}$ While the official criteria of the recruits' physical examination do not mention race at all, the statement does concur with historian Daryle Williams's argument that wartime propaganda largely visually represented the Brazilian Army as all-white. ${ }^{42}$ The fact is, however, that between 5.5 to 20 percent of the febianos were "black" and that between 33.4 and 43.3 percent of the Brazilian troops were neither "white" nor of Asian descent. ${ }^{43}$ These figures are in accordance with Brazil's 1940 census that used similar racial categories and shows that at the same time 35.84 percent of the Brazilian population fell into the category of "Blacks and Mixed-race" (pretos e pardos). ${ }^{44}$

Other testimonies claim that on several occasions higher officers in the FEB gave the order to exclude black soldiers from parades, to restrict them to inner columns, or to at least make sure they would march afoot and will not ride vehicles. Such orders meant to publicly present the marching Brazilians as "white," or with the lack of another option, to at least create a racial hierarchy between soldiers.

These events became public knowledge as early as 1949 when one of the accounts in the critical collected volume Depoimentos de oficais da reserve sôbre a F.E.B. narrated in three short paragraphs two incidents in which black soldiers were ordered to be moved to the end of a parade or completely excluded from marching. Both incidents happened while the soldiers were still in Brazil, and the authors assign these order to a specific, unnamed general. ${ }^{45}$

About a year later, the communist newspaper $O$ Patriota that targeted military readership and was circulated in the army offered a harsh criticism of General Zenóbio da Costa, the commander of the FEB's infantry. In a sarcastic column titled "Biography: Our "Illustrious Bosses" the author mocked the general's bravery and military wisdom and also reminded the audience that:

We all know how he commanded taking the blacks out of the FEB's parade formation and we all know of his recent recommendations to the colonels to include blacks as military surplus troops. In this, like the other [actions], the head of the R.M. complies like a servant to the racist Yankee patrons. ${ }^{46}$

Almost five decades afterwards veteran Cássio Abranches Viotti narrated in his memoir occasions when the high officers gave similar racist orders. The first was before the FEB set sail to Italy when General da Costa ordered: "the blacks have to march afoot." ${ }^{47}$ The second occurred in Italy when each 
platoon was ordered to send one soldier to parade in Naples. The officers were told to select soldiers who exhibited good conduct and were warned that "it is prohibited to appoint blacks." ${ }^{48}$

How can we reconcile veterans' multiple claims of the lack of racism in the Brazilian army and society in light of the reports of racial prejudice in the FEB? Answering this question, Maximiano and Oliveira argue that Brazilians viewed their relative lack of institutionalized discrimination (in comparison to the United States) as evidence of a less-malignant form of racial discrimination in Brazil. ${ }^{49}$ While this explanation is plausible and logical, as we have seen above, veterans' claims about the absence of racism in Brazil are not relative, but definite ones, and Brazilian authors clutched at the idea that Brazil lacked racial discrimination entirely. A close reading of the accusations of racism, however, suggests another answer.

First, authors condemn the racism and discriminatory practices they report. Thus, Viotti describes the order prohibiting blacks from riding in the first occasion as "bizarre" (esdrúxula) and "absurd" (absurdo) and José Bento Teixeira de Salles, who wrote the introduction to Viotti's memoir, also expressed his surprise of the racist order. ${ }^{50}$ Arruda too, uses the two paragraphs about the discrimination in the parades to criticize the FEB's high command and its lack of "'Democratic' spirit" (espírito 'democrático').

While reporting episodes of racial discrimination, those who narrate them use a second strategy to distance themselves and the rest of the FEB from the discriminatory act by assigning the prejudice to someone else. Arruda, Viotti, and $O$ Patriota either name or hint that a certain general, or a very selected group of high-ranking officers, are responsible for such orders. Dequech, like $O$ Patriota, distances himself from racist orders by arguing that the enlistment requirement were imposed by the United States.

Another strategy to reject the racist acts authors use is to inform the readers that while a discriminatory order was given, the low-ranking officers and the troops did not obey it. Viotti elaborates on both occasions how he and others resisted the orders. In the first episode he tells of a captain who disobeyed the order and commanded his black troops to ride their jeeps, was later excluded from the FEB and was sent to serve in the island of Fernando de Noronha as a punishment (but later, due to his patriotism, found his way back to the FEB and fought in Italy). In the second case, Viotti sent a black soldier to represent his platoon in the parade against explicit orders not to do so, and, although the soldier was rejected-Viotti does not mention by whom-no actions were taken against him. ${ }^{51}$

Thus, despite the ideal description of the Brazilian moral high ground version of race relations, racism did exist, but among whom exactly? Authors make sure their readers know they find these acts illegitimate, that they resisted them, and that the ones responsible for them are domestic or foreign "others." 
Collectively, these strategies absolve the authors, the FEB's rank and file, and, by extension, the Brazilians as a whole from taking responsibility over the existing racism in their society.

The attempt to absolve the majority of Brazilians from racial prejudice through various literary strategies, however, is only partially successful. Occasionally, authors reveal their own patronizing perceptions of AfroBrazilians. For example, in his oral testimony Rubens Resstel tells of the segregation in the US Army and then comments on it, saying that "But this was the Americans' question, and we had nothing to do with it. Our blacks were treated equally to everyone else [my emphasis]" 52 Resstel is not unique, and other veterans use variations of the phrase "our blacks" (nossos negros), as well. Another example can be found in Corrêa Netto's reflections on Ghana, where he arrived by plane on his way to Italy. According to him, Accra is a former Portuguese port, "from where our ancestors took the captive blacks to Brazil." 53 The phrase is a window to Corrêa Netto's self-identity as the descendent of the Portuguese slave traders and not the enslaved Africans. The usage of the plural first voice projects the authors' self-identity on their assumed readers, and the possessive form is condescending.

In contrast to textual testimonies, comic artists cannot avoid illustrating their protagonists' physical characteristics and ignore their racial identification. Here, again, the FEB war comics are useful for the identification of racial attitudes that are missing from most texts. Out of forty-two issues of eleven different Brazilian comic magazines published between 1957 and the mid1970s, which include one hundred and five FEB-related comic-stories, only seven stories included Afro-Brazilians protagonists. Moreover, in four of these stories the Afro-Brazilians merely serve in the background of the plot with no effect on the narrative (see Table 1). As discussed above, the comic narratives textually strive to refute racial prejudice by celebrating Brazilian "Racial Democracy" and disprove the inferiority of nonwhites. At the same time, visually they reinforce the discriminatory characterization by eliminating traces of Afro-Brazilians and replacing the "Racial Democracy" ideology with its earlier "whitening" one.

\begin{tabular}{|c|c|c|c|}
\hline & Story & Main protagonist & Role played \\
\hline 1 & The FEB's Bloodiest Battle & No & Neutral \\
\hline 2 & A pracinha in a Wardrobe & Yes & $\begin{array}{l}\text { Negative. Runs from } \\
\text { the enemy }\end{array}$ \\
\hline 3 & The Braves of Campinas & No & Neutral \\
\hline 4 & 17 of Abataia & Yes, but not alone & Positive \\
\hline 5 & A Sad Christmas Song & No & $\begin{array}{l}\text { Qualifies other soldiers' } \\
\text { longing for home by } \\
\text { bringing with him his } \\
\text { sad holiday memories }\end{array}$ \\
\hline
\end{tabular}




$\begin{array}{llll}6 & \text { Drama at Sea } & \text { No } & \text { Somewhat neutral } \\ & \text { Weekend at the Front } & \text { Yes, one of two } & \text { Positive, but still runs } \\ & \text { for help in Front of } \\ & \text { the enemy while his } \\ & \text { comrade stays and } \\ & \text { holds them. }\end{array}$

Table 1: Afro-Brazilians in FEB Comics. Sources: VIDAL, Paulo; COLIN, Flavio. A mais sangranta batalha da FEB. Coleção de aventuras, n. 9. Editora Garimar. 1957; WEBSTER [?], Luiz. Um pracinha dentro um armário. Coleção de aventuras, n. 12. Editora Garimr. 1958; PORTO, Hélio; DILOM, Juarez. O bravos de Campinas. Coleção de aventuras, n. 18. Editora Garimar. 1958; OESTERHELD, Hector Germán; PRATT, Hugo. 17 de Abataia. Coleção de aventuras. Unnumbered; PAROCHE, Alberto André. Um triste canção de Natal. Combate, n. 23. Editora Taika; [PAROCHE, Alberto André]. Drama no mar. Diário de Guerra, n. 1-12. GEP; MATTOS, Milton; RODRIGUES, Edmundo. Fim de semana no Front. Almenaque diário de Guerra. GEP.

In the few cases where Afro-Brazilians are represented in the comics and are assigned a role in the plot, their image is not flattering. In the only story in the sample that has an Afro-Brazilian main protagonist, he does not demonstrate much bravery. In this 1958 story, "A pracinha in a Wardrobe," when the soldier finds himself in a village taken by the Germans, he acts in an unusual way - in comparison to many other narratives in the FEB comicsand hides in a cabinet. ${ }^{54}$ When the opportunity presents itself, he runs back to the Brazilian lines and saves himself. The same motif exists in the earlier mentioned story "Weekend at the Front." ${ }^{\text {" }}$ After discussing the superiority of Brazilian race relations over North American and European ones, and after the soldiers successfully socialize with Italian women and ride back to their camp, they encounter the enemy. At this moment of truth, the two soldiers act differently: the white soldier defends his position and fights the enemy while the black one leaves the battlefield and runs to call for help. While the story's text eulogizes Brazilian race relations, the development of the plot paints the two soldiers in different colors. Even in the story "Drama at Sea," the image of the fleeing Afro-Brazilian repeats itself. ${ }^{56}$ The story tells of the sinking of a Brazilian ship by a German submarine. In a single frame, an Afro-Brazilian tells of those sailors and passengers who tried to save themselves but were trapped in a sinking ship. At first glance, the usage of the Afro-Brazilian to emphasize the tragedy and the vulnerability of the Brazilians in contrast to the aggressiveness and provocativeness of German behavior seems to bear no special meaning. However, several frames earlier another behavior is described when another sailor, a white one, is calming a frightened child and orders the child to follow him so the child can be saved. Once again the Afro-Brazilian 
tries to save himself while the "non-Afro-Brazilian" is taking care of the child and shows responsibility.
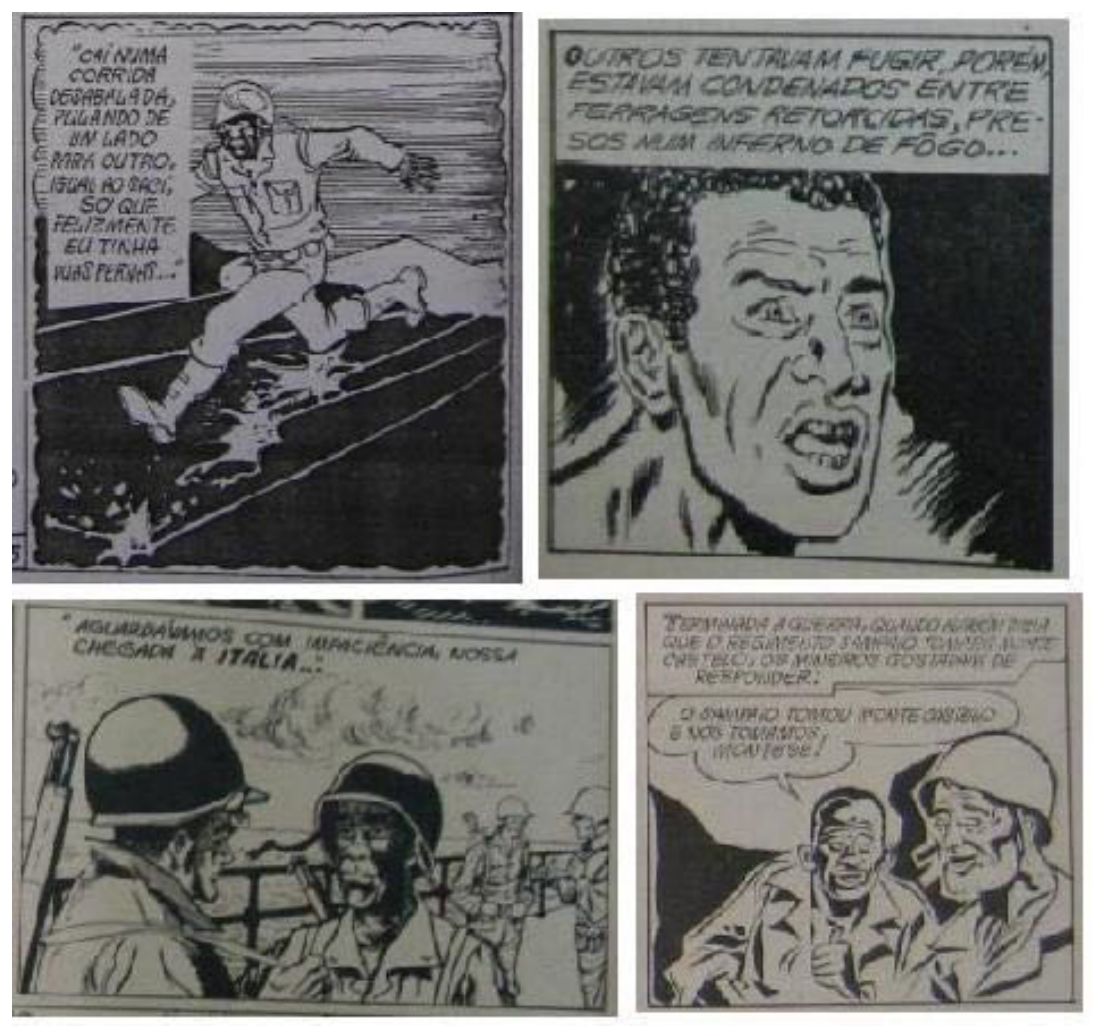

Figure 1: Afro-Brazilians in FEB Comics. In the top two illustrations AfroBrazilian protagonists run from the enemy and abandon the ship to save themselves. In the bottom two examples Afro-Brazilians are minor protagonists who appear in a neutral way in the plot. Clockwise starting top left: WEBSTER [?], Um pracinha dentro um armário. p. 5/4; [PAROCHE]. Drama no mar. p. 6/4; PORTO. O bravos de Campinas. p. 5/5; VIDAL. A mais sangranta batalha da FEB. p. 6/4

In contrast to these two stories, where Afro-Brazilians are assigned cowardly behavior, the Afro-Brazilian sergeant in Hector Germán Oesterheld and Hugo Pratt's "17 of Abataia" demonstrates loyalty and bravery when he mocks his German captor and refuses to surrender any information. ${ }^{57}$ This positive image of an Afro-Brazilian pracinha, however, was created by an Argentinean and an Italian for an Argentinean readership, and only later was it translated into Portuguese. ${ }^{58}$

The visual aspect of the comic medium exposes the dissonance between its textual claims for a functioning Racial Democracy and the visual whitening of the soldiers. In the few cases where comics do represent Afro-Brazilians, 
they are assigned negative roles and cowardice. The only self-reflective and self-critical comment on this reality can be found in Alberto André Paroche's early 1970s story "A Sad Christmas Song." 59 In a single panel three Brazilian soldiers discuss their longing for home on Christmas Eve. While two soldiers talk about the beaches, families, presents, and parties, the third one, illustrated with stereotypical African phenotypes, brings up a socio-economic tension when he says Christmas is for the rich, and it is no reason for a party in his favela (see Figure 2). Not only does the author associate blackness with poverty, but he also does it in a way that leaves the reader with a bitter inequality of inequality and false comradeship in his mouth.

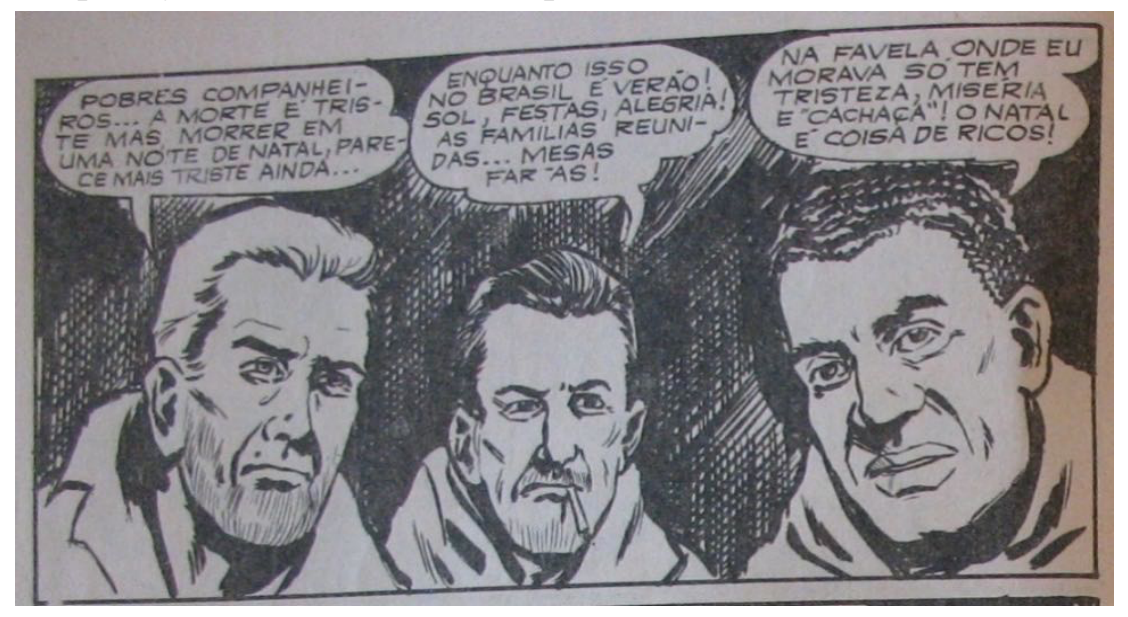

Figure 2: The Afro-Brazilian character on the right — note the curly hair, wide nose and broad lips - "In the favela where I used to live there is only sadness, misery and 'cachaça'! Christmas is for the rich!" Source: PAROCHE. Um triste canção de Natal. p. 8/1.

\section{Conclusion}

When the Brazilian febianos arrived in Italy they encountered people of other nationalities. As they observed how other people interacted, behaved, and lived, the differences between the others and themselves became apparent. While some of these encounters left Brazilians with much to desire, their shock of the tense race relations they saw among their North American allies filed them with pride for their own social norms. The study of how pracinhas of all walks of life reacted to another racial system and in turn reflected on their own is a useful window to how ordinary Brazilians - rather than intellectual and ideology-producers - understood the ideology of the Racial Democracy that characterized their society at the time.

While post-World War II scholars meticulously exposed the shortcomings, faults, and imperfections of the Brazilian assumed racial 
harmony, the veteran who shared their war-time experiences demonstrated strong conviction and pride in their cordial and equitable race relations. They could not ignore, however, the continuous existence of racism in the Brazilian society, but in order not to shutter the ideal society in its existence they strongly believed they found ways to distance such behaviors from themselves as individuals and as a collective. Their attempts to create and live the society they claimed they have, however, could not completely hide the fact that some of them did hold racist attitudes, and sometimes they were caught off-guard and exposed them.

The febianos' war against totalitarianism on European soil exposed the contradiction between the values they fought for and those of the authoritarian Estado Novo who sent them. Similarly, the pracinhas' condemnation of North American institutional discrimination and racism also turned Brazilians' attention to their own system of race relations, of which they were proud, and sometimes concerned, and the future proved both sentiments correct.

\section{NOTAS}

1 MAXIMIANO, Cesar Campiani. Trincheiras da memória: brasileiros na campanha da Itália, 1944-1945. Tese de Doutorado, Universidade de São Paulo, 2004. p. 118-19.

2 SILVEIRA, Joel. O inverno da Guerra. Rio de Janeiro: Objetiva, 2005.

3 SILVEIRA, Joaquim Xavier da. A FEB por um soldado. Rio de Janeiro: Editora Nova Fronteira, 1989. p. 58.

4 See, for example, VIDIGAL, Geraldo. O aprendiz de liberdade: do Centro XI de Agosto à 2.a Guerra Mundial. São Paulo: Saraiva, 1988. p. 66, and MIRANDA, Antônio Batista de. Guerra: memorias...destino... Belém: A.B. de Miranda, 1998. p. 98.

5 Alon Confine offers a similar perspective by German soldiers, especially on the Western Front and particularly in Paris. See: CONFINO, Alon. Germany as a Culture of Remembrance: Promises and Limits of Writing History. Chapel Hill: University of North Carolina Press, 2006. p. 248-49.

6 Ibid., p. 222.

7 PRATT, Mary Louise. Imperial Eyes: Travel Writing and Transculturation. London; New York: Routledge, 1992. p. 4.

8 GREENBLATT, Stephen. Marvelous Possessions: The Wonder of the New World. Chicago: University of Chicago Press, 1991. p. 3.

9 For the argument that Brazilians and American soldier only had little contact, and that it was impaired by language barriers see: SMALLMAN, Shawn C. The Official Story: The Violent Censorship of Brazilian Veterans, 1945-1954. The Hispanic American Historical Review, v. 78, no. 2,1998. p. 236.

10 Interview with SCHIRMER, Benno Armindo. In: MOTTA, Aricildes de Moraes (Org.). História oral do exército na Segunda Guerra Mundial. Rio de Janeiro: Biblioteca do Exército Editora, 2001. Tomo 7, p. 116.

11 Interview with LIMA, Miguel Ferreira de. In: MOTTA. Op. Cit., Tomo 6, p. 345. 
12 ALBRICKER, Jarbas. Memórias de um pracinha. Belo Horizonte: Imprensa Oficial do Estado de Minas Gerais, 1965. p. 18.

13 Interview with MEDEIROS, Elza Cansanção. In: MOTTA. Op. Cit., Tomo 5, p. 281; Interview with ARANHA, Oswaldo Gudolle. In: MOTTA, Op. Cit., Tomo 6, p. 210.

14 NETTO, Alípio Corrêa. Notas de um expedicionário medico. São Paulo: ALMED, 1983. p. 30 .

15 Interview with CAMMAROSANO, Diaz Sebastião. In: MOTTA. Op. Cit., Tomo 8, p. 127.

16 See, for example Interview with BORGES, Waldemar Dantes. In: MOTTA. Op. Cit., Tomo 4, p. 185 and Interview with SZAJNFERBER. Salli. In: MOTTA. Op. Cit., Tomo 4, p. 284.

17 Interview with GONÇALVES Helio Amorin. In: MOTTA. Op. Cit., Tomo 4, p. 317; Interview with ROCHA, João Evangelista Mendes da. In: MOTTA. Op. Cit., Tomo 5, p. 109. These views are shared by other Allied participants in the Italian campaign. See, for example: Report by the Supreme Allied Commander Mediterranean Field-Marshal The Viscount Alexander of Tunis to the Combined Chiefs of staff on The Italian Campaign: 12th December 1944 to 2nd May 1945. London: His Majesty's Stationary Office, 1951. p. 22.

18 A notable, unrepresentative, exception can be found in Ahemar Rivermar de Almeida's explanation that every military unit retreats occasionally, and inexperienced ones even more so. Interview with ALMEIDA, Adhemar Rivermar de. In: MOTTA. Op. Cit., Tomo 6, p. 107.

19 Interview with RESSTEL, Rubens. In: MOTTA. Op. Cit., Tomo 3, p. 37.

20 Interview with COSTA, Octávio Perreira da. In: MOTTA. Op. Cit., Tomo 5, p. 7.

21 Interview with LOPES, Ernani Ferreira. In: MOTTA. Op. Cit., Tomo 5, p. 201.

22 Quoted in MOTLEY, Mary Penick (Org.) The Invisible Soldier: The Experience of the Black Soldier, World War II. Detroit: Wayne State University Press, 1975. p. 346-47.

23 GIBRAN, Daniel K. The 92nd Infantry Division and the Italian Campaign in World War II. Jefferson, NC: McFarland \& Company, 2001. p. 56, 70.

24 OLIVEIRA, Dennison de; MAXIMIANO, Cesar Campiani. Raça e forças armadas: o caso da campanha da Itália (1944/45). Estudos de História, v. 8, no. 1, 2001. p. 173.

25 Interview with MADEIROS. Op. Cit., p. 281; See also Interview with RESSTEL. Op. Cit., p. 36.

26 See, for example: Interview with CAMMAROSANO. Op. Cit., p. 127.

27 Interview with ALBUQUERQUE, João Ferreira. In: MOTTA. Op. Cit., Tomo 3, p. 152.

28 See, for example: Interview with GONZALES, Antonio. In: MOTTA. Op. Cit., Tomo 3, p. 117 and Interview with MEDEIROS. Op. Cit., p. 294.

29 Black and White Fight Together for Brazil, Why not for U.S.A.?. Afro American, June $17,1944$.

30 Brazil Shows How Democracy Should Work. New York Amsterdam News, June 17, 1944.

31 MALLIET, A. M. Wendell. World Fronts. New York Amsterdam News, July 1, 1944.

32 FBI Library, Federal Surveillance of African Americans, 1920-1984, Adam Clayton Powell FBI File (HQ 100-51230: 11) p. 43, Clipping dated July 1, 1944. Question of the Week. People's Voice.

33 HARRINGTON, Ollie. Black, White, Red Brazilian Troops March, Socialize Freely In 
Naples. The Pittsburgh Courier, August 5, 1944.

34 JOHNSON, Max. 1st Expeditionary Force from Brazil Now in Italy. Baltimore AfroAmerican, August 5, 1944.

35 Many veterans recall such stories. See, for example: SILVA, Jairo Junqueira da. In: MOTTA. Op. Cit., Tomo 3. p. 70-71; Interview with RESSTEL. Op. Cit., p. 50.

36 PAROCHE, Alberto André; ROSSO, Nico. Estrada 64. Combate, n. 37. Editora Taika, p. 13/4. The story also appeared in Almenaque combate, n. 6-74.

37 PAROCHE, Alberto André; ROSSO, Nico; GERALDES, Rogério. Alberta. Combate, n. 25. Editora Taika, p. 4/3.

38 Interview with FARIAS, Heraldo Carlos Leopoldo de. In: MOTTA. Op. Cit., Tomo 6, p. 132.

39 MATTOS, Milton; RODRIGUES, Edmundo. Fim-de-semana no 'Front'. Almenaque diário de Guerra. GEP, p. 9/5-6, 10/1.

40 Oliveira. Op. Cit., p. 160.

41 DEQUECH, José. Nós estivemos lá. Curitiba: Legião Paranaese do Expedicionário, 1995. $2^{\mathrm{a}}$ ed., p. 31.

42 For the medical enlistment criteria see: GONÇALVES, Carlos Paiva. Seleção Médica do Pessoal da FEB: história, funcionamento e dados estatísticos. Rio de Janeiro: Biblioteca do Exército, 1951. P. 162. For the argument about the war propaganda see: WILLIAMS, Daryl. Culture Wars in Brazil: The First Vargas Regime, 1930-1945. Durham: Duke University Press, 2001. P. 7-8.

43 The reason for the range of percentile is the multiplication of racial categories and the different ways they can be grouped into broader racial categories. RIBEIRO, Patrícia da Silva. Em luto e luta: construindo a memória da FEB. Rio de Janeiro, Tese de Doutorado, Programa de Pós-graduação em História, Política e Bens Culturais, CPDOC/ Fundação Getúlio Vargas, 2013. p. 163-170.

44 CENSO DEMOGRÁFICO [DO 1940]: POPULAÇÃO E HABITAÇÃO. Rio de Janeiro: IBGE, 1950. Quadro 1, p. 1. For the race in the Brazilian census see: NOBLES, Melissa. Shades of Citizenship: Race and the Census in Modern Politics. Stanford, CA: Stanford University Press, 2000.

45 ARRUDA, Demócrio Cavalcanti de. Impressões de um infante sôbre o commando. In: ARRUDA, Demócrio Cavalcanti de et. al. (Org.). Depoimento de oficais da reserva sôbre a F.E.B.. São Paulo: Instituto Progresso editorial, 1949. p. 63-64.

46 Biografia: Nossos 'ilustres chefes'. O Patriota, Abril de 1950, p. 5. Archived in Archivo Púplico do Estado do Rio de Janeiro, DPS, Dossies, 30.418 Jornais Comunistas nas forças armadas. Like the sentiment expressed in the personal narratives, here too racism is attributed to the North Americans. Being a communist publication, however, the perception of Brazilian society as a "Racial Democracy" takes a Marxist-Leninist twist with international relations being understood in terms of the imperialistic North Americans and the struggle for national independence.

47 VIOTTI. Cássio Abranches. Crônicas de guerra: a força expedicionária brasileira na Itália. Belo Horizonte, 1998. p. 20.

48 Ibid., p. 76.

49 OLIVEIRA. Op. Cit., p. 175. 
50 VIOTTI. Op. Cit., p. 20-21. SALLES, José Bento Teixeira de. Aresentação. In. VIOTTI. Op. Cit., p. 8.

51 Both cases are narrated in VIOTTI, Op. Cit., p. 21, 76-77. For other reports on disobeying discriminatory orders see ARRUDA. Op. Cit., p. 64.

52 Interview with RESSTAL. Op. Cit., p. 37.

53 NETTO. Op. Cit., p. 11. The phrase is not a later edition from the time of publication, and it can be found in the entry from August 22, 1944, in Corrêa Netto's war diary. The diary is deposited in the small archive of the Museu Histórico da Faculdade de Medicina da USP (FMUSP, also known as Museu Prof. Carlos da Silva Lacaz) in a folder titled "Correa Netto, Alipio."

54 WEBSTER [?], Luiz. Um pracinha dentro um armário. Coleção de aventuras, n. 12. Editora Garimr. 1958.

55 MATTOS, Milton; RODRIGUES, Edmundo. Fim de semana no Front. Almenaque diário de Guerra. GEP.

56 [PAROCHE, Alberto André]. Drama no mar. Diário de Guerra, n. 1-12. GEP.

57 OESTERHELD, Hector Germán; PRATT, Hugo. 17 de Abataia. Coleção de aventuras. Unnumbered.

58 Also notice that this story was independently adopted into comics by a Brazilian. In his version there is no Afro-Brazilian at all. See: MONTEIRO, Gutemberg. Os 17 de Abetaia. Coleção de Aventuras, n. 15. Editora Garimar. 1958.

59 PAROCHE, Alberto André. Um triste canção de Natal. Combate, n. 23. Editora Taika.

Artigo recebido em fevereiro de 2016. Aceito em maio de 2016. 